\title{
Efficacy of Diphenylamine, Ultra-low Oxygen, and Ethylene Scrubbing on Scald Control in 'Delicious' Apples
}

\author{
O.L. Lau \\ Industry Research Program, Okanagan Federated Shippers Association, c/o Agriculture Canada \\ Research Station, Summerland, B.C. VOH 1ZO, Canada
}

Additional index words. Malus domestics, watercore, flesh browning, low-oxygen injury, postharvest physiology

\begin{abstract}
Incidence of scald in nontreated and DPA (2000 mg-liter ${ }^{-1}$ )-treated 'Delicious' apples (Malus domestics Borkh.) was assessed after 8.5 months in $1.5 \%$ or $0.7 \% \mathrm{O}_{2}$ plus $1.5 \% \mathrm{CO}_{2}$ at $0.2 \mathrm{C}$, with and without $\mathrm{C}_{2} \mathrm{H}_{4}$ scrubbing. Incidence of scald was high in non-DPA fruit held in $1.5 \% \mathrm{O}_{2}$, and DPA treatment reduced scald in fruit held in $1.5 \%$ or $0.7 \% \mathrm{O}_{2}$. Scald control was better with $0.7 \% \mathrm{O}_{2}$ and no DPA 'treatment than with $1.5 \% \mathrm{O}_{2}$ and a DPA dip. Ethylene scrubbing had no effect on scald in fruit held in $0.7 \%$ or $1.5 \% \mathbf{0}_{2}$. Susceptibility of fruit to scald-and flesh browning exhibited seasonal variation, which was related to the differences in fruit maturity and the amount of watercore at harvest, respectively. Chemical name used: diphenylamine (DPA).
\end{abstract}

Control of scald in sensitive apple cultivars, such as 'Delicious', is achieved by treating the fruit with DPA or 6-ethoxy1,2,-dihydro-2,2,4-trimethyl quinoline (ethoxyquin) immediately following harvest (Hardenburg, 1965; Smock, 1955, 1957). Recent concerns about the effects of chemicals on human health and the environment are creating uncertainty over the long-term future use of DPA and ethoxyquin. Therefore, a search for nonchemical control of apple scald is required. One approach has been low $\mathrm{O}_{2}$ (Chen et al., 1985; Little and Taylor, 1981; Patterson and Workman, 1962; Roberts et al., 1963), another low $\mathrm{C}_{2} \mathrm{H}_{4}$ (Dover, 1985; Knee and Hatfield, 1981; Liu, 1977).

British Columbian-grown 'Delicious' could benefit from the use of low $\mathrm{O}_{2}$ for controlling scald because it does not develop much purple-brown skin discoloration in low- $\mathrm{O}_{2}$ atmospheres (Lau, 1990). 'Delicious' apples stored in $0.5 \% \mathrm{O}_{2}$ plus $1.5 \%$ $\mathrm{CO}_{2}$ at $0.5 \mathrm{C}$ for 7 months followed by 2 months in air at $0 \mathrm{C}$ and 7 days in air at $20 \mathrm{C}$ had a skin discoloration incidence of $8 \%$ compared to $61 \%$ in 'Spartan' and $44 \%$ in 'McIntosh'.

The purpose of the present study was to determine the efficacy and potential problems associated with the use of low- $\mathrm{O}_{2}$ atmospheres $(1.5 \%$ or $0.7 \%)$, DPA treatment $\left(2000 \mathrm{mg} \cdot\right.$ liter $\left.^{-1}\right)$, and $\mathrm{C}_{2} \mathrm{H}_{4}$ scrubbing to control scald of 'Delicious' apples.

\section{Materials and Methods}

Eight replicates (80 fruit each; 10 fruit for prestorage fruit maturity measurement and 70 fruit for storage study) of 'Delicious' apples were obtained each year (1986 and 1987) from each of eight random grower lots at a commercial controlledatmosphere (CA) storage facility. The eight $(2 \times 2 \times 2)$ treatments were: \pm DPA (2000 mg.liter $), 0.7 \%$ or $1.5 \% \mathrm{O}_{2}$ plus $1.5 \% \mathrm{CO}_{2}$, and $\pm \mathrm{C}_{2} \mathrm{H}_{4}$ scrubbing.

Fruit grade, flesh firmness, internal $\mathrm{C}_{2} \mathrm{H}_{4}$, concentration (IEC), starch index, and incidence of watercore of each grower lot were determined before storage on a 10-fruit sample using methods described by Lau $(1985,1989)$. The IEC values were used to calculate the percentage of fruit with IEC $>1 \mu \mathrm{l} \cdot \mathrm{liter}^{-1}$, a value generally deemed indicative of the onset of fruit ripening.

Received for publication 28 Dec. 1989. Appreciation is extended to Agriculture Canada Research Station, Summerland, B. C., for use of research facilities and to R. Yastremski for her assistance. The cost of publishing this paper was defrayed in part by the payment of page charges. Under postal regulations, this paper therefore must be hereby markedadvertisement solely to indicate this fact.
Four of the eight replicates from each grower were dipped into a DPA suspension before storage in $0.7 \%$ or $1.5 \% \mathrm{O}_{2}$ plus $1.5 \% \mathrm{CO}_{2} \pm \mathrm{C}_{2} \mathrm{H}_{4}$ scrubbing. The samples were held in $0 \mathrm{C}$ air for $24 \mathrm{hr}$ and then sealed in $0.2 \mathrm{C}$ steel cabinets $\left(1.7 \mathrm{~m}^{3}\right)$ equipped with a blower fan $\left(2.8 \mathrm{~m}^{3} \cdot \mathrm{min}^{-1}\right)$. The desired $1.5 \%$ or $0.7 \%$ $\mathrm{O}_{2}$ levels were established within 24 or $32 \mathrm{hr}$ after sealing by purging with $\mathrm{N}_{2}$, and the $1,5 \% \mathrm{CO}_{2}$ levels were established within 4.5 days by fruit respiration and additions of $\mathrm{CO}_{2}$ as required. Each low- $\mathrm{C}_{2} \mathrm{H}_{4}$ cabinet was equipped with an internal $\mathrm{C}_{2} \mathrm{H}_{4}$ scrubber containing $10 \mathrm{~kg}$ of Purafil beads (potassium permanganate-alumina; Circul-Aire, Montreal, Canada) spread evenly over four trays $(25 \times 70 \times 3 \mathrm{~cm})$. The volume of air movement and amount of Purafil used exceeded those suggested by Blanpied (1985). Ethylene in the low- $\mathrm{C}_{2} \mathrm{H}_{4}$ cabinets was below $1.0 \mu \mathrm{l} \cdot$ liter $^{-1}$ during the first 3 (1986) or 6 (1987) months of storage and never exceeded 3.7 (1986) or 4.7 (1987) $\mu \mathrm{l} \cdot$ liter $^{-1}$ during subsequent months of storage. Content in the high- $\mathrm{C}_{2} \mathrm{H}_{4}$ cabinets $\left(1986=397 \mu\right.$ l.liter ${ }^{-1}$, with a range of $\mathrm{O}$ to 819 $\mu 1$. liter $^{-1} ; 1987=345 \mu 1$. liter $^{-1}$, with a range of $\mathrm{O}$ to 772 $\mu$ l.liter ${ }^{-1}$ ) was increased gradually by adding $\mathrm{C}_{2} \mathrm{H}_{4}$ at a rate of $=100 \mu \mathrm{l} \cdot$ liter $^{-1} \cdot \mathrm{month}^{-1}$ to simulate accumulation of $\mathrm{C}_{2} \mathrm{H}_{4}$ in non- $\mathrm{C}_{2} \mathrm{H}_{4}$-scrubbed CA storage. Storage $\mathrm{C}_{2} \mathrm{H}_{4}$ was monitored by gas chromatography and adjusted weekly. Storage $\mathrm{O}_{2}$ and $\mathrm{CO}_{2}$ were monitored daily with a paramagnetic $\mathrm{O}_{2}$ analyzer and infrared $\mathrm{CO}_{2}$ analyzer, respectively. Atmospheres were maintained at the desired levels, $\pm 0.2 \%$, by scrubbing with hydrated lime (10 to $15 \mathrm{~g} \cdot \mathrm{kg}^{-1}$ of fruit) to remove $\mathrm{CO}_{2}$, purging with $\mathrm{N}_{2}$ to remove excess $\mathrm{O}_{2}$, or adding air or $\mathrm{CO}_{2}$. Storage temperature was maintained at $0.2 \pm 0.3 \mathrm{C}$.

Table 1. Characteristics of 'Delicious' apples before storage ( $n=8$ grower replicates per year).

\begin{tabular}{|c|c|c|}
\hline $\begin{array}{c}\text { Fruit characteristics } \\
\text { before storage }\end{array}$ & 27 Sept. 1986 & 26 Sept. 1987 \\
\hline $\begin{array}{l}\text { Extra-fancy and fancy grade } \\
\text { (\% of fruit) }\end{array}$ & $\pm 11^{z}$ & 81 \\
\hline Flesh firmness $(\mathrm{N})$ & \pm 4 & $72 \pm$ \\
\hline $\begin{array}{l}\text { Internal } \mathrm{C}_{2} \mathrm{H}_{4} \text { concn } \\
\quad\left(\mathrm{IEC}, \mu \mathrm{l} \cdot \mathrm{liter}^{-1}\right) \\
\text { IEC > } 1 \mu \mathrm{l} \cdot \text { liter }^{-1}\end{array}$ & $4.5 \pm 5.4$ & $7.7 \pm$ \\
\hline $\begin{array}{l}\text { (\% of fruit) } \\
\text { Starch index }(0-9) \\
\text { Watercore }(\% \text { of fruit) }\end{array}$ & $\begin{aligned} 15 & \pm 14 \\
2.2 & \pm 1.0 \\
24 & \pm 27\end{aligned}$ & $\begin{aligned} 54 & \pm 33 \\
2.9 & \pm 0.4 \\
2.5 & \pm 4.6\end{aligned}$ \\
\hline
\end{tabular}

${ }^{\mathrm{z}}$ Mean $\pm \mathrm{SD}$. 
After CA storage and also after a period in air at 0C (specified in each table) plus 7 days in air at 20C, subsamples of 10 apples from each storage treatment were assessed for flesh firmness, alcohol flavor, and storage disorders by methods described by Lau (1985, 1989). Evaluation of alcohol flavor was performed by 16 panelists for each storage treatment, using a 1 to 5 scale, where $1=$ none, $3=$ detectable, and $5=$ strong. Storage disorders were determined on 10-fruit (first examination) or 40fruit (second examination) samples. Data were subjected to analysis of variance and means separated by an F test.

Table 2. Percent of scald in DPA (2000 mg-liter ${ }^{-1}$ )-treated and nontreated 'Delicious' apples held for 8.5 months in $1.5 \% 0_{2}$ or $0.7 \%$ $0_{2}$ plus $1.5 \% \mathrm{CO}_{2}$ at $0.2 \mathrm{C}$, with and without $\mathrm{C}_{2} \mathrm{H}_{4}$ scrubbing $(\mathrm{n}=$ 8 orchard replicates per year).

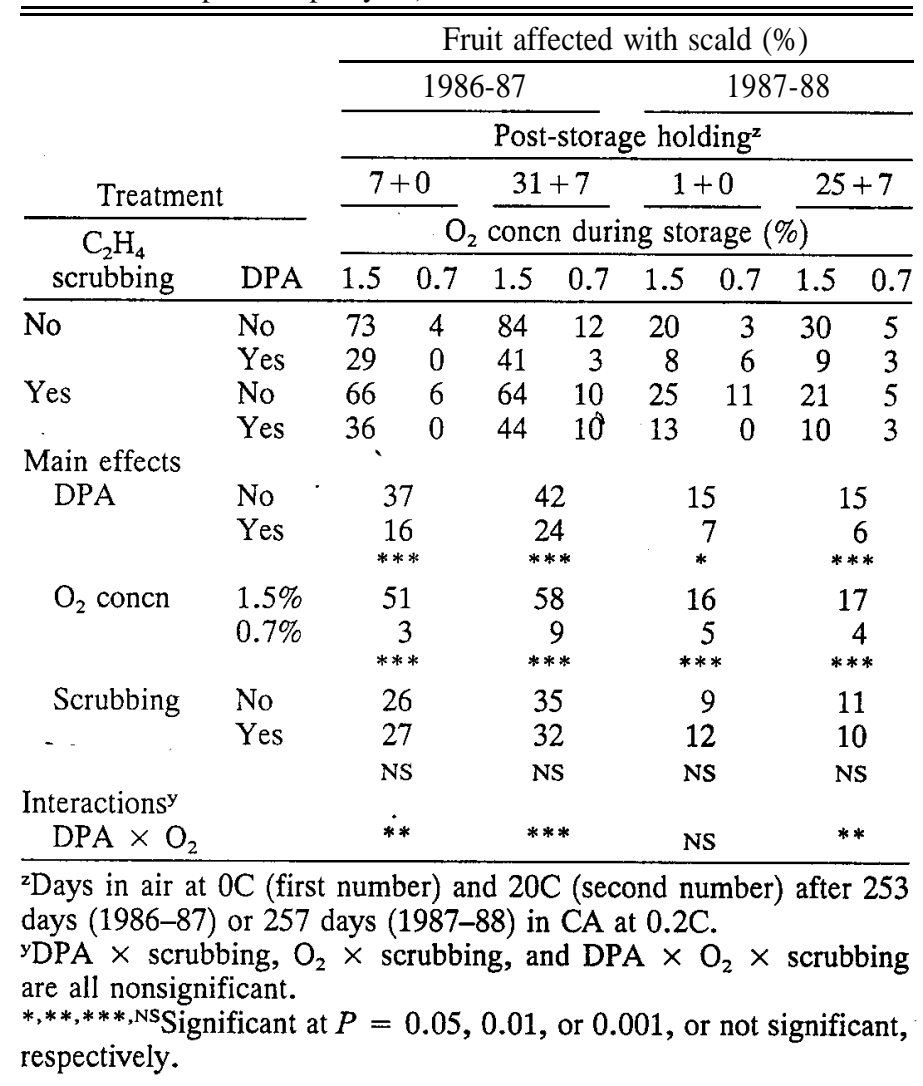

\section{Results and Discussion}

Harvesting was delayed in 1987 because of poor color development; thus, the 'Delicious' apples were more mature than in 1986 (Table 1). This difference could explain, at least in part, why non-DPA fruit had less scald in 1987 than in 1986 (Table 2). Scald susceptibility is negatively related to harvest maturity (Chen et al., 1985; Hardenburg, 1965; Little and Taylor, 1981). Dry and hot weather before harvest may also predispose the fruit to scald (Fidler, 1956; Little and Taylor, 1981). I (unpublished data) found a high incidence of scald in non-DPA, airstored 'Delicious' apples picked at a starch index of $\leq 2.3$. The high incidence of watercore in the 1986 crop predisposed the fruit to flesh browning during storage (Table 3). Kopec and Masek (1970) found that the creation of anaerobic conditions in watercore-affected tissues increased susceptibility of fruit to browning.

Incidence of scald in fruit stored in 1.5\% $\mathrm{O}_{2}+1.5 \% \mathrm{CO}_{2}$ was reduced markedly, but not always eliminated, by the postharvest DPA dips in both years (Table 2).

Fruit not treated with DPA showed a mean scald value of $48 \%$ (1986 and 1987 combined) in $1.5 \% 0_{2}$, compared with a mean value of $7 \%$ in $0.7 \% \mathrm{O}_{2}$. Scald control was better with $0.7 \% \mathrm{O}_{2}$ and no DPA treatment than with $1.5 \% \mathrm{O}_{2}$ and a DPA dip. The effect of DPA was not as pronounced in $0.7 \% \mathrm{O}_{2}$ as in $1.5 \% \mathrm{O}_{2}$ because scald incidence was very low in $0.7 \% \mathrm{O}_{2}$ (Table 2). Low- $\mathrm{O}_{2}$ injury (purple-brown skin discoloration) was negligible in non-DPA fruit held in $0.7 \% \mathrm{O}_{2} ; \approx 0.6 \%$ of the fruit was affected in 1986 and none in 1987. Alcohol flavor rating of the fruit was not adversely affected by storage in $1.5 \%$

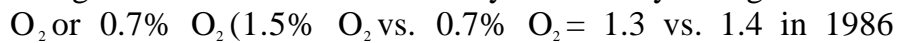
and 1.7 vs. 1.6 in 1987 . Thus, the benefit of storage at $0.7 \%$ outweighs the risk of low- $\mathrm{O}_{2}$ injury.

A low- $\mathrm{C}_{2} \mathrm{H}_{4}$ atmosphere reduced scald in 'Bramley's Seedlings' (Knee and Hatfield, 1981) and 'Delicious' (Liu, 1977) apples held in a $2.5 \%$ to $3.0 \% \mathrm{O}_{2}$ atmosphere. However, in the present study, $\mathrm{C}_{2} \mathrm{H}_{4}$ scrubbing was ineffective in reducing scald in 'Delicious' apples held in a static $1.5 \%$ or $0.7 \% \mathrm{O}_{2}$ atmosphere (Table 2). Patterson and Workman (1962) found that high $\mathrm{C}_{2} \mathrm{H}_{4}$ did not increase scald in 'Gallia Beauty' apples over that obtained from constantly renewed air. Dover (1985) found inconsistency in $\mathrm{C}_{2} \mathrm{H}_{4}$ scrubbing and scald reduction in 'Bramley's Seedling' apples. He obtained the best results when the fruit was harvested 1 week before the onset of autocatalytic $\mathrm{C}_{2} \mathrm{H}_{4}$ production and when storage $\mathrm{C}_{2} \mathrm{H}_{4}$ concentrations were maintained below $1 \mu \mathrm{l} \cdot$ liter $^{-1}$ for most of the storage period.

Table 3. Incidence and severity of and correlation coefficients between watercore at harvest and flesh browning after storage.

\begin{tabular}{|c|c|c|c|c|c|c|c|c|c|}
\hline \multirow{5}{*}{$\begin{array}{c}\text { Expression } \\
\text { of } \\
\text { physiological } \\
\text { disorder } \\
\end{array}$} & & & \multicolumn{4}{|c|}{ Flesh browning } & \multicolumn{3}{|c|}{ Correlation coefficient } \\
\hline & & & \multicolumn{2}{|c|}{1986} & \multicolumn{2}{|c|}{1987} & \multicolumn{2}{|c|}{1986} & $1986+1987$ \\
\hline & \multirow{2}{*}{\multicolumn{2}{|c|}{$\begin{array}{l}\text { Watercore } \\
\text { at harvest }\end{array}$}} & \multicolumn{2}{|c|}{$253+31+7^{z}$} & \multicolumn{2}{|c|}{$257+25+7^{2}$} & \multicolumn{2}{|c|}{$253+31+7^{2}$} & $255+28+7^{z}$ \\
\hline & & & \multicolumn{7}{|c|}{$\mathrm{O}_{2}$ concn during storage $(\%)$} \\
\hline & 1986 & 1987 & 1.5 & 0.7 & 1.5 & 0.7 & 1.5 & 0.7 & 1.5 \\
\hline Fruit affected (\%) & 24 & 2.5 & 11 & 10 & 0 & 0 & $0.90^{* * *}$ & $0.86^{* *}$ & $0.92^{* * *} \quad 0.89^{* * *}$ \\
\hline Score $(300 \text { max. })^{y}$ & 52 & 3.8 & 18 & 13 & 0 & 0 & $0.91^{* * *}$ & $0.90^{* * *}$ & $0.91^{* * *} 0.92^{* * *}$ \\
\hline
\end{tabular}

${ }^{2}$ Days in $1.5 \% \mathrm{O}_{2}$, or $0.7 \% \mathrm{O}_{2}$ plus $1.5 \% \mathrm{CO}_{2}$ at $0.2 \mathrm{C}$ (first number), in air at $0 \mathrm{C}$ (second number), and in air at 20C (third number).

${ }^{y}$ Based on assigned values of 0 for free from disorder, 1 for slight, 2 for moderate, and 3 for severe disorder, multiplied by the percentage of fruit affected by the disorder.

$* * * * *$ Significant at $P=0.01$ or 0.001 , respectively. 
In conclusion, $0.7 \% \quad \mathrm{O}_{2}$ is a viable alternative to DPA for scald control in 'Delicious' apples harvested at commercial maturity (i.e., with an adequate proportion of the skin being red) (Table 1, extra-fancy and fancy grade). Ethylene scrubbing does not appear to serve a useful function in control of the disorder in $1.5 \%$ or $0.7 \% \mathrm{O}_{2} \mathrm{CA}$ storage.

\section{Literature Cited}

Blanpied, G.D. 1985.1984-85. Handbook for low ethylene CA storage of McIntosh and Empire apples. Pomology Dept., Cornell Univ., Ithaca, N.Y.

Chen, P. M., K.L. Olsen, and M. Meheriuk. 1985. Effect of lowoxygen atmosphere on storage scald and quality preservation of 'Delicious' apples. J. Amer. Soc. Hort. Sci. 110:16-20.

Dover, C.J. 1985. Commercial scale catalytic oxidation of ethyleneas applied to fruit stores, p. 373-383. In: J.C. Roberts and G.A. Tucker (eds.). Ethylene and plant development. Butterworths, London.

Fidler, J.C. 1956. Scald and weather. Food Sci. Abstr. 28:545-554.

Hardenburg, R.E. 1965. A review of literature on harvesting, handling, storage and transportation of apples. U.S. Dept. Agr./Agr. Res. Serv. Pub]. 51-4. p. 194-215.

Knee, M. and S.G.S. Hatfield. 1981. Benefits of ethylene removal during apple storage. Ann. Appl. Biol. 98:157-165.

Kopec, K. and V. Masek. 1970. The dynamics of watercore and browning in stored apples. Rostl. Vyroba 16:1067-1074. [Hort. Abstr. 41:5803 (1971)].

Lau, O.L. 1985. Storage procedures, low oxygen, and low carbon dioxide atmospheres on storage quality of 'Golden Delicious' and 'Delicious' apples. J. Amer. Soc. Hort. Sci. 110:541-547.

Lau, O.L. 1989. Storage of 'Spartan' and 'Delicious' apples in a lowethylene, $1.5 \% \quad 0_{2}$ plus $1.5 \% \mathrm{CO}_{2}$ atmosphere. HortScience $24: 478$ 480 .

Lau, O.L. 1990. Responses of British Columbia-grown apples to lowoxygen and low-ethylene controlled atmosphere storage. Acts Hort. 258:107-114.

Little, C.R. and H.J. Taylor. 1981. Orchard locality and storage factors affecting the commercial quality of Australian Granny Smith apples. J. Hort. Sci. 56:323-329.

Liu, F.W. 1977. Varietal and maturity differences of apples in response to ethylene in controlled atmosphere storage. J. Amer. Soc. Hort. Sci. 102:93-95.

Patterson, M.E. and M. Workman. 1962. The influence of oxygen and carbon dioxide on the development of apple scald. Proc. Amer. Soc. Hort. Sci. 80:130-136.

Roberts, E. A., E.G. Hall, and K.J. Scott. 1963. The effects of carbon dioxide and oxygen concentrations on superficial scald of Granny Smith apples. Austral. J. Agr. Res. 14(6):765-777.

Smock, R.M. 1955. A new method of scald control. Amer. Fruit Grower 75(11):20.

Smock, R.M. 1957. A comparison of treatments for control of apple scald disease. Proc. Amer. Soc. Hort. Sci. 69:91-100. 